\title{
3
}

\section{Novel Readers and Novel Reading}

By 1850 American reviewers had accepted the novel as the literary art form of the nineteenth century. Its preeminence derived from its extraordinary popular appeal, which had been evident in the United States a quarter-century or more earlier. The union of popularity and artistry was something new in the history of literature: since literary art had always been the property and practice of an elite, popular modes had never before entered into critical discourse. Like other major literary forms, the novel was thought to represent the spirit of its age; and the spirit of the nineteenth century consisted of the emergence of the people as a political and cultural force. During the second quarter of the century reviewers and serious novelists introduced the concept of the "better novel." But no matter how vigorously reviewers strove to create public esteem for what they considered superior examples of this form, they could not forget-indeed, as Americans they did not want to forget-that the popular reader who had made the form had to be its final judge.

Deference to public opinion in evaluating particular novels is expressed in many reviews. The North American, looking back on the career of Sir Walter Scott in April I 833, recalled that when Waverley first appeared, "men beheld it with as much perplexity, as the out-break of a revolution. Critics were in sad straits, having nothing wherewithal to measure it . . . but the public, without asking their opinion, gave decisive judgment in its favor." Knickerbocker, attacking what it deemed the inflated repu- 
tation of William Gilmore Simms, asserted that "novelists, poets, composers, and all other authors whose productions appeal to the feelings, may snap their fingers at critics and reviewers, for they can neither be written up or written down. The public may be persuaded to adopt a false religion or a false theory in political economy, as they have been often; but all the reviewers in Edinburgh and Westminster could not induce them to read a dull novel or remember prosy poetry" (April I 846). Such deference exists in unresolved tension with the critics' efforts to elevate public taste. Reviewers of the time assumed that without the seal of popular approval a novel could not be put forward as a great work of art. And they also held that, though popularity was by no means in itself the test of artistic merit, one could never assume the opposite: that popularity implied poor art. The automatic correlation, in our own times, of popularity with inferiority involves a cynicism with respect to the popular mind that was not to be found among American reviewers during the I 840 ond i 850 os.

Although reviewers could not ultimately resolve the tension between aesthetic absolutism and a belief in the role of the people as final judges of a popular form, they did try. Their most common strategy was to suppose that the people were "rising," largely by their own efforts in an enabling society, and that their inherent instincts for quality, increasingly called out by opportunity, would make them appreciate better books as these were called to their attention. So a Grabam's reviewer in February I 849 observed of Cornelius Mathews's Moneypenny that "the work is exceedingly interesting, evinces a strong grasp of character, is well written, and while it deserves and will reward the attention of the more tasteful class of readers, it will tend to give a more important, because more numerous and sensitive class, a higher notion of the requirements of romance." According to the Editor's Table in Harper's for November I 859, opponents of cheap literature "affirm that, were it not for this flimsy stuff, readers would take to better books. But this is a mistake. There is no sort of rivalry between the two kinds of publications. . . . It is out of this body of readers - the million-that the widening circle of those who enjoy the masters in English literature is supplied. . . . No doubt it would be desirable for a refined taste, a genuine appreciation of the best merits, to be formed without this inter- 
mediate stage of progress. But this is simply impracticable. . . The safest rule in literature, as in government, is to believe that the people are the soundest judges and the sharpest guardians of their own interest. If left to themselves, they will not go very far astray."

This habit of accepting the people as final judges may account for the lesser severity of American as opposed to English novel reviewing, a phenomenon pointed to on both sides of the Atlantic. Even for American reviewers, however, there were two sorts of limiting case: the extremely popular novel that was trash, and the work of high quality that was clearly not likely to be popular. But a judgment about the trashiness of a fictional work almost always derived from the book's morality, so that questions of artistry could be ignored in such cases. And reviewers usually handled the work of limited appeal by showing how, for one or another reason, it was not really a novel, thus freeing it from expectations of popular success. This is how reviewers presented Longfellow's Kavanagh (a critical though not popular success in its day) and Melville's Moby-Dick, and this is how Hawthorne presented himself. The strategy was well intentioned, for it tried to ensure that nobody expecting a novel would be disappointed by getting something else. In particular instances, however, such a strategy could lead to a smaller readership. This may have happened with Melville. If authors were pretending to write novels in order to capitalize on the popularity and prestige of the genre, their intentions might be contravened by the "helpful" reviewer who was trying to ensure a fair reading for the work.

Overall, and to a much greater degree than is the case today in journalistic (and even more in academic) criticism, American reviewers of the 1840 and 1850 os were sensitive to the reader who completed the novel's reality. They never lost the sense (so lacking in various current academic theories of reader response, including the concept of "interpretive communities," which in practice are composed of students reading required novels and writing about them for a grade and under professorial surveillance) that readers were autonomous beings, selecting novels by choice and for pleasure. Accordingly, too, reviewers were regularly alert (though not, on that account, necessarily correct) to questions of the make-up of the reading audience. 
Novel Readers

Who, then, as the reviewers saw it, read novels? In the broadest sense, everybody read them, from the most cultivated and leisured classes on down. Just how far down the social strata the pool of novel readers was thought to go may be sensed in a comment from the conservative New York Review for October I 837. The reviewer was assessing Catharine Sedgwick's Live and Let Live, a didactic story arguing that servants should be treated like contractual employees rather than inferiors or menials. "We should not quarrel," said the review, "if the book were to be confined to the party whose failures are described. But it will be extensively read on the other side; and in its present form it is precisely the book we should wish to keep out of the hands of a numerous class of servants." Sedgwick was advised to write a companion story setting forth the obligation of servants to their "mistresses" and to bind it with Live and Let Live in a single volume. Obviously the reviewer believed that many members of the servant class read novels.

If everybody read novels, then the class distribution of the audience was proportional to the class distribution of the nation, hence consisting largely of "the people." Here we meet a typical American vagueness. In the Harper's Easy Chair on cheap literature quoted above, the use of pronouns suggests that Harper's did not include its own very large number of readers among the people: if left to themselves, they will not go very far astray. At times reviewers meant the working class, at other times the middle class, and at times both. Of course, social commentators in America have always been fuzzy where thinking about class is concerned, and novel critics are not cultural theorists. Ultimately, in novel criticism, the audience seems to be divided into two groups, correlated loosely with presumed class membership. First, and more numerous, were ordinary or "mere" novel readers looking for pleasure and reading for story; second, there was a small group of cultivated, discreet, intelligent, educated, tasteful, thoughtful readers who wanted something more than, but not incompatible with (reviewers hoped), the tastes of the ordinary reader. Because this smaller group was thought of as cultivated and educated, its membership was naturally drawn from a higher 
social class than the ordinary reader. It was the degree of education, rather than class membership, that constituted a distinction between two groups of readers.

But when novel readers were thought of as a subset of the class of general readers the question of education or class became even less important. First, some people read more novels than others; second, some people read novels to the virtual exclusion of any other kind of book. The weight of ordinary readers in the scale increased greatly if they, as novel readers, read almost nothing else and also did most of the reading: if, that is to say, the educated, tasteful lawyer or merchant read one novel each year while the ordinary reader went through fifty. Moreover, if-as reviewers sometimes seemed to fear-that educated man was not much of a reader of anything, then the preferences of the "ordinary" novel reader became more significant still. Essentially, it became much more important to bring more or different novels to the people who already read them than to bring new groups of readers to the novel. Reviewers had to spend much more time telling ordinary readers that some worthwhile story was nevertheless interesting than telling readers of taste that this interesting story was nevertheless worthwhile. In this way, the assumed constituency of the novel reader controlled the remarks in reviews.

Yet another aspect of the habits of ordinary novel readers implied by their fondness for reading novels was a preference for the form itself over any particular example of it. They liked to read many novels. This approach made it certain that no novel could be written that was so perfect as to make the form obsolete, any more than a superb dinner might mean the end of eating. Readers might, to be sure, read Waverley over again from time to time and enjoy it. But how much better was a new Waverley novel every year! In other words, the practice of novel reading tended to favor authors who were capable of producing many novels, and the novel itself developed as a form whose individual examples, no matter how beautifully crafted, had to expect to be quickly "used up." (And not because the reader had grasped the meaning of a particular novel, but because he or she wanted repetition with variation rather than a simple repetition of the novel-reading pleasure.) Since some notion of permanence has always attached to the idea of great art, this transitoriness inten- 
sified the difficulty of defining the "better novel" within the popular framework. To have a work judged the best novel of the season, or of the month, was perhaps the most an author might realistically hope for.

Other ways of classifying readers than by education or class (though not unrelated to these matters) involved age, gender, and family membership. In this excerpt from a laudatory essay on the Warner sisters from the North American for January i 853 , such concepts can be seen. "As far as we know the early history of $T$ he Wide, Wide World, * it was, for some time, bought to be presented to nice little girls. . . . Elder sisters were soon found poring over the volumes, and it was very natural that mothers next should try the spell. . . . After this, papas were not very difficult to convert. . . . We are much mistaken if The Wide, Wide World, and Queechy, have not been found under the pillows of sober bachelors. . . . They were found on everybody's table, and lent from house to house." The circle widens to involve the sober bachelor at last, but its center is in the home. The novel is at home in the home's heart, with the children and the women. Though the Warners' books, being domestic fiction, were especially home centered, this connection between family and fiction is the one most frequently on the reviewers' minds. "The novel, at present, more than any other variety of literature, becomes a household book, and in some sort a member of the family" (Knickerbocker, December I 858). As the one form of nineteenth-century amusement that comes into the home from the outside, it is opposed to amusement that one must leave home to enjoy. "Let us not ungratefully forget," Godey's wrote in an Editor's Table on cheap literature (June I 853), "what vast amount of benefit these attractive productions induce, by fostering a love of purer recreation than the young would otherwise cultivate, and by withdrawing the mind from habits of questionable or decidedly pernicious influence, to the sacred precincts of domestic affection."

This connection does not mean, however, that novels functioned as the occasion for family group activities like evening

\footnotetext{
*The spelling, capitalization, and italicization of novel titles have been silently regularized in quoted material from reviews. In many cases books were published anonymously, identified as "by the author of . . .," and the reviews did not mention the author's name; in some such instances I have supplied that name.
} 
reading aloud. Instances of this use for novels are recorded in nineteenth-century diaries and letters, as is reading aloud to sick people, but reviewers mainly described reading as a solitary activity carried on in the home. The novel is passed from house to house and from reader to reader within the house, but each person reads it privately. The novel thus supports the all-important home by providing pleasures within its precincts, yet at the same time it encourages a dangerous privatism and individualism by providing a solitary, self-centered activity. If it strengthens the home against outside forces, it also weakens the social character of the home itself. In domestic ideology home is a fortress against the world and a corrective to atomistic, nonsocial human tendencies. These goals are in tension, and the home is a fragile construct. Could another fragile construct, the novel, serve the home if it encouraged social fragmentation in its interior? The question that the exciting and self-gratifying content of popular novels raises is duplicated by the isolating nature of the novelreading activity itself. The matter becomes even more sensitive when we perceive that the two great classes of novel readers, when audience was approached from a family perspective, were the young and the female-those for whom the home is supposed to be all in all and whose domestication is what creates home in the first place. No reviewer, whatever other social, political, or religious approach he or she took, could even briefly entertain an antidomestic thought; hence the role of the novel in the lives of young people and women was an issue of great moment.

In this extract from the Christian Examiner for January I 847, these questions emerge clearly. "Profligacy has seldom devised a more cunning or successful scheme for laying waste the pure principles of a people, than when she sent forth her dissolute panderers, in the disguise of scribbling romancers, to enervate and demoralize, with their wretched stuff bound up between yellow covers, the strong-hearted youth of New England. . . . These seductive emissaries create artificial notions of success in life; they spread a bad taste for extravagant manners; they foster bad passions; they break the peace of happy homes; they entice the young of both sexes from the healthful and steady pursuits of the country into the city, - the wide and wicked city, where virtue loses its crown, where temptation plies a double power and all its wiliest stratagems for the stranger, where the freshest 
hearts are blasted and the bright hopes go out in terrible darkness." Thus where the Godey's reviewer sees cheap literature as enforcing the citadel of home, the Christian Examiner reviewer sees it as a Trojan horse. But the family is a democracy like society at large: "we are aware," the review continues, "of the difficulties that beset every effort to correct this abuse. We know how ill-advised a direct attempt at its suppression might prove, and that the very earnestness of a prohibition, either parental or civil, might only stimulate curiosity, and cause that reading to be done clandestinely, in the spirit of theft, which is now done openly. In fact, we cannot look for any sudden check to be interposed. The art of printing has been invented."

This rhetoric is more like that of our own day, and less like that of the Puritan era, than might at first glance be supposed. It attributes no more than weakness to the youthful mind. Depravity is an adult quality entering the home in which youth is protected and innocence preserved. The young person's response to fiction is different from the adult's, because youth is less experienced, less knowledgeable, and much more excitable and impressionable. A Peterson's review of Evelyne; or, The Heart Unmasked, said, "we question the propriety of such novels, when we remember how very young most of their readers are"; another review of a novel called The Two Families said that "in an age like this, when so much harm is done by improper fictions, a writer like this should be welcomed to every fireside, and receive the thanks of every parent" (August I 845; August I 852). The "danger to be apprehended" from French novels, according to the New York Review (August 1846), "is almost exclusively confined to the more youthful class of readers, whose imaginations are excited, and passions inflamed, by the highly-wrought pictures of sensual indulgence with which they are filled and the exuberant life with which they abound. Those of maturer age will find in their coarseness an antidote to their immorality." The Sunshine of Gray Stone, "carrying with it a certain quiet and pleasing interest . . may be safely recommended to American parents" (Arthur's, May i 854)-not, of course, for their own reading, but for their children's. In our time such rhetoric is seldom applied to novels but is commonplace with respect to those new intruders into the home space, television and popular music.

All reviewers who distinguished youthful from mature au- 
diences assumed that the mature were the wiser and better readers. Youth had less experience, greater love of pleasure, and stronger passions. These passions were chiefly, though not exclusively, attributable to emerging sexuality. Thus the distinction between youth and adult suggested a split between body and mind, with the youthful mind less capable of artistic discrimination because it was still enmeshed in its physical casing. The adult stage, at which passion had presumably been mastered, called for a more mental and consequently superior novel.

On occasion, however, youth and maturity were contrasted as different mentalities. Sartain's, reviewing George Sand in November 1847 , observed that "notions in reality crude and narrow, seem in the light of her genuis and expressive power, full of generous, all-embracing humanity, and remedial wisdom. Young and ardent minds, fascinated by her grace, her noble sentiments, her tenderness, her sympathy with all those passionate feelings in which so many young people believe happiness to consist, adopt her as a leader. . . . Next to the pleasure of talking about one'sself to a sympathizing listener, is the expression of one's secret thoughts by another and a superior mind. It is a gratification of egotism without the shame. . . . We cannot consider her a safe companion for youthful or excitable minds." Here the leading aspect of the youthful mentality is its egotism. In other reviews it is idealism, though, interestingly, idealism and egotism are seen as related qualities. "At sixteen," a reviewer in the Southern Literary Messenger commented, Lamartine's Confidential Disclosures "might have enraptured us. . . . But at the period of the present writing, we have years enough over our head and have seen sufficient of this naughty world of ours to cause us to lay aside some of the frivolity and nonsense of our boyhood" (June I 849). The young prefer Dickens, but the old, "who have 'seen the skeleton,' who know how hollow a thing life is, will choose Thackeray; and though not yet very aged ourselves, we must confess to being better satisfied with the realities we find in Pendennis, than with the visionary, though beautiful creations in most of the novels of Boz" (Peterson's, January i 853). Where sexuality is at issue, reviewers complain about novels that are too adult; where mentality is at issue, they complain about novels that are not sufficiently so. Questions we might wish to consider about the development of better novels during the second quarter 
of the nineteenth century need to be put in the context of this audience division. Did the novel get better, in reviewers' eyes, because it became less truthful and hence more adapted to its function of preserving youthful innocence, or because it became more truthful and hence more capable of initiating youth into life's realities? And in either case, what had these effects to do with the form of the novel or the purpose for which youth read novels?

The second category of ordinary novel reader besides the young was the female. Her taste was supposed to reflect a fastidious delicacy: the American Review assured her, for example, in April I 846 that in the works of the Vicomte d'Arlincourt "all is chaste and correct." It recommended "to the fairer portion of our readers" that they "procure and read his novels, in which they will find abundance of romantic incident, a fund of historic information, and much of the honey of sentiment, untainted by the poison of a refined sensuality." In November i 85 I it judged that a book called Sunbeams and Shadows, and Buds and Blossoms "would be a great favorite with all lady readers. The authoress wields a graceful pen, and paints characters with no little skill. There is a fine undertone of religious sentiment and earnest feeling pervading the whole, and elevating it above the ordinary novel."

This view of the female reader is only what we would expect, but it implies a very different reader from that excitable, impressionable, sensually vulnerable youth for whose innocence the reviewers were so much concerned. Yet, since half or more of the novel-reading youth were females, these two imagined readers must be identical. Indeed, the two ideas of readership are incompatible when referring, as they do, to the same group of people. In one case the reader is attracted to, in the other repelled by, the intense, passionate, and exciting. Were the reviewers reporting on a real personality change that came over young women as they reached adulthood-one precisely opposite from that which came over young men? There is unquestionably a real gap in American Victorian thinking concerning the transition from adolescence to maturity in women. But this gap may be the result of willful blindness, a reluctance to perceive (in the particular case of novel reading) that young women were prominently among those who loved dangerous novels. Moreover, for passionate novels of dubious morality to be tremendously popular they had to 
be read avidly by females of all ages. Even if, however, the grown woman relinquished the beloved reading of her girlhood, it had been a part of it, and hence the dream of female innocence involved a measure of falsification. If novels were the nineteenthcentury version of the apple in the home's Garden of Eden, then women were the great apple eaters. In this sense the prevalent ideology of domesticity was grounded in a deep, though possibly unconscious, hypocrisy. The realities of novel reading contradicted popular theories of the female character, a matter that male reviewers may not have noticed. Though it is difficult to imagine that the women reviewers completely failed to see the inconsistencies, their silence on the topic is easily understandable.

\section{Novel Reading}

However they might elaborate on this idea, all reviewers acknowledged that the basis of the novel-reading experience was interest, which might vary in intensity but could never be entirely forgone and which, at its greatest, could be so exciting as to be painful. People liked novels because they alone among literary types produced this experience. They did so by telling stories about sympathetic, humanlike beings beset by difficulties, thus engaging curiosity and arousing suspense. Of course mimesis of some sort was at the heart of the novel, and not until much later in critical history - when theory became able to think of novels apart from readers and hence apart from affect, as well as to question the very idea of the human being-was it possible to conceive of nonrepresentational novels. At the same time, strict "realism" was not necessary for novels to be effective; indeed, as we will see, realism might well reduce interest. Mimesis thus could be thought of with no difficulty as utterly conventional and schematic, a set of gestures defining the novel's agents as human beings and their surroundings as the real world.

The heart of the experience of reading novels, the North American asserted as early as April I 828, lies in "the interest, the natural, irrepressible interest, which the passions of men will always take in lively descriptions of passion, the absorbing heed which their affections will render, while the world stands, to 
writings which address and excite them." Like calls to like, and human passions respond to their own description. "For every man recognizing in himself the elements of character delineated," Harper's wrote in an Easy Chair for February i 860, "recognizes also the fidelity of the picture of their inevitable operation in life-sees himself openly revealed-his secret sympathies, impulses, ambitions-his vices, his virtues, his temptations; and follows with terrible fascination the course of his undeveloped future-passes thoughtful and alarmed, and hangs back upon the very edge of sorrow and destruction."

Whether the basis of interest in the representation lay in action, in character represented by behavior, or in "the secret springs of passion," the fixed concept was that of interest. Knickerbocker praised Bulwer's Zanoni for "the deep interest which it excites" and the "curiosity awakened, stimulated, enhanced to almost painful excitement" (May I 842). Eugene Sue's Martin the Foundling, according to the Democratic Review for October I 846, "abounds in those picturesque scenes, startling incidents, and novel mysteries which, in the works of Sue, rivet the attention, and lead us on from page to page with alternations of pleasure, doubt, and thrilling expectation." Jane Eyre "will create a deeper interest and seize more strongly on the hearts of the reading public, than any work of fiction that has appeared since Miss Bremer's Neigbbors. . . . The story is of singular interest, and rivets the attention to the last. . . . whoever commences it will not lay it down until the spell of enchantment is broken by the ending of the book" (Literary World, January 29, 1848). "An absorbing fiction," a Peterson's reviewer wrote of The Divorced, by Charlotte Bury. "No one can take up the book without perusing it breathlessly to the end." Emerson Bennett's The Forged Will was "a story of absorbing interest, and one that will have an immense sale. The author seizes the reader's attention, in the very first chapter, and triumphantly retains it until the very last" (both March I 847). A later Peterson's review speculated on the popularity of E. D. E. N. Southworth, deciding that "she owes this eminent success to the absorbing interest which she infuses into her narratives" (November I 854); another said that her Retribution "is one of the most intensely absorbing stories we ever read" (October i 856).

At the point where the interest of the novel became positively 
painful, the ordinary reader and the reviewer tended to part company. While acknowledging the inevitability of the popularity of tremendously exciting books, reviewers often felt that their educative responsibilities required them to qualify their praise. A Southern Literary Messenger review explained in November I 843 that the appeal of Sue's Mysteries of Paris lay in "its fulness of incident and the intensity of its interest" which "have procured and will procure for it thousands of readers" but "render it objectionable to a pure, moral taste." Taking a complementary approach, a Harper's reviewer approved of The Watchman because it made no appeals to "an imaginative craving for unnatural excitement" (September I 855), while the Tribune praised Catharine Sedgwick because she "has never appealed for the interest of her works to the morbid love of excitement" (August i 5, i 857). The problem for these reviewers was to draw the line between natural and unnatural excitement, and this problem was essentially unsolvable. Only the Ladies' Repository with its view that all excitement is unnatural - or more precisely that all excitement, though natural, is a mark of original sin-could escape the issue, and it did so, inevitably, by condemning the novel genre as a reprobate form. Those reviewers who wanted to justify novel reading, and those who even more ambitiously wanted to elevate the form and claim the rank of artist for novelists, could only waffle around the agreed-on fact that the novel was based on and directed toward the secular passions. They could not finally separate aesthetic from moral value, and on many occasions morality called for a different end from that of pleasure, and hence for a different aesthetic form.

It was a feature of this pleasure, as I have already noted, that it created the desire for more novels. In January I 839 the New York Review referred to "those who rely on works of fiction for their intellectual food"; in April it said, "the thirst for light reading is fed and not quenched by being gratified." Reviewers often observed, with disapproval, that love of novels was itself likely to become a passion. They emphasized this point by consistently describing it, as in the review above, with metaphors drawn from bodily appetites implying physical stimulation, intoxication, and addiction. Drinking and eating were the activities most compared to novel reading. Of course the Ladies' Repository used this rhetoric: "rum and romances are just about equal in their power to 
intoxicate and stultify their victims." "The vain stories of the fugitive press . . . produce a moral intoxication. . . . The novel reader becomes little better than a lunatic, and passes his hours in dreams of rapture, or of anguish." "Man is a reading animal. . . . He will have something; and if he cannot obtain sound food, he will devour the infected and poisonous" (December I 843, September I 844 , July i 847 ).

But the Repository was not alone. The North American referred to "multitudes of men, so-called, besides women and children, who fall, with a wolf-like appetite, on husks, which, if the animals were readers, would appear intended for creatures much lower than mankind" (January I 846); sometimes "the appetite for fiction becomes a sickly craving, from much cramming with crude, unnatural food" (January I $85 \mathrm{I}$ ). As for the popularity of foreign novels: "thousands, nay, millions of readers and writers drink from this bounteous source, and feed on this foreign aliment, till the whole complexion of their thoughts is tinged with it" (January I 852). The Literary World referred to French novels as "highly-spiced and unhealthy French dishes" (March I 7 , I 847). A Southern Literary Messenger review compared the effects of highly wrought fictions to "the honey gathered from the flowers of the rhododendron; it creates a madness in those who taste it" (February I 842); another said that "the rank inveterate novel readers have been stuffed to surfeiting" (August I 843).

Knickerbocker said Howard Pinckney had "stirring adventures, and love scenes enough to satisfy the most craving appetite" (November I840). The American Review in April I 846 likened reading Eugene Sue's novels to "literary dram-drinking" and deplored the "large class of readers . . . who crave excitement and seek to stimulate their palled appetites with something highly spiced." The Tribune wrote of the "spiced wine" of popular modern fiction and "the taste of many readers, pampered and spiced up with all manner of heating condiments" (April 28, I 849; August I 5, I 857). Grabam's said that "the feverish power" of Bulwer's Zanoni "exacts a feverish interest, which is as unhealthy as it is stimulating; but this intellectual dram-drinking is now so common that the charge of morbid sentiment brought against a book operates as a puff" (August I 850). A later review referred to the "popular craving for stimulants" in the class of novels (April I 855). Putnam's in May I 853 referred to the "feast of fiction" and 
said Thackeray's was "like good sound old wine, though we have tasted them a thousand times, the actual smack upon the lips is always a new and luscious sensation." Harper's in April I 853 called Villette "a piquante luxury to the sated taste of regular readers of fiction."

Images of eating and drinking were not confined to instances of censure; on the contrary, those arguing for "wholesome" fiction did so with the same metaphors. In June i 844 Peterson's called for better novels: "the heads of families would do well to consider that the taste for what is called light reading is natural, nay! inevitable in youth - that it will usually gratify itself, in one way if not in another-and that the wisest course is to feed it with proper aliment instead of leaving it to 'gorge on garbage.' "The Home Journal for March I4, i 855, proposed that those concerned with improving public taste provide "pure and wholesome aliment in this form for the mental appetite of the young." Fiction, according to the Literary World, may act "as an intellectual cordial to restore the healthy action of other faculities" (June I 2, I847); we "lay Scott aside, refreshed and invigorated" (June 24, I 848); "however torpid and inactive the inventive faculty may be in any individual reader, if there be any life left in him, the administering of Kaloolab will be an admirable dose to rouse it into full vitality" (June $24, \mathrm{I} 848$ ); fiction is generally praiseworthy because it provides one's "higher faculties" with "nutriment denied them in real life" (November 24, I 849). When you read a good novel "your heart aches, your soul smiles, you feel the delight and satisfaction streaming along your nerves" (Harper's, May I 854); the "quiet pictures" of Wesley "make an agreeable and soothing impression on the mind" (Harper's, July I 854). Godey's in June 1853 described the mission of good light fiction: "to invigorate the intellect without fatiguing it," affording "that relaxation the mind requires."

In all these examples the good novel seems to have a medicinal effect, either tonic or soothing, in strong contrast to the exciting novel, which agitates and irritates. But discussion of both effects shares a conception of the novel as a substance taken into the body, there to work an effect beyond the reader's control. The good book is one that "tastes good" or "is good for you" in a physical way. Occasionally, most circumspectly, and mostly before $\mathrm{i} 850$, reviewers approximated novel reading to sexual excite- 
ment, perhaps suggesting that novels gave occasion for masturbatory activities. For Knickerbocker, reviewing Richard Hurdis, "the object of novelists in general . . . appears to be to seize the public mind, and hold it with a sort of enchantment; a fascination which arises from the power which a master will exercise over the volition of inferior spirits, leading them captive, and exciting them with the stimulus they love most. Accordingly, there are no novels so saleable as those which lead the affections step by step into a sphere of irritating tumult, fevering the blood with uncontrollable sympathies, and steeping the interior man in a sea of voluptuous sensuality" (September I 838). The American Review commented that Sue "excites those evil impulses, which slumber in the hearts of the purest like the hidden embers within the volcano. . . . No virtuous woman can or should read the sentiments and feelings exhibited ... without feeling the blush of shame and indignation mantel on her cheeks" (March I 846). Observe that "can or should"; in all this rhetoric of jaded appetites and stimulated curiosity we may well forget that the chief readers of fiction were supposed to be the pure of heart-the young and the female. The Democratic Review wrote of the "delightful involuntary thrill which the pathos of Sterne and Dickens so often produced" (October I 848); Grabam's praised Wesley because "there is no attempt to produce striking effects by jerks or spasms of diction or incident" (July I 854). If women and children were what ideology held them to be, they would not be reading for the pleasures here imputed to the novel.

This description of cheap literature from the Christian Examiner for May I 845 certainly reads like a pamphlet on masturbation: "there are loads of books emptied daily into the market, which instead of imparting to the reader's intellect, will, or affections any healthy spring, kindling in him any pure emotion, or nerving him for any manly struggle, only enervate and defile him, eating away all the elastic energies of his being. There is just attractiveness enough in their style, or just fascination enough in the succession of incidents they narrate, to make them palatable to a diseased, unnatural appetite." The Ladies' Repository declared (January I 845) that popular fiction was "prostituted to the gratification of the grossest sensuality," its object "the murder of time, the dissipation of the intellectual energies, and the corruption of the heart; whose tendency is to habituate the mind to a 
morbid excitement which totally unfits it for healthy and rational action."

Clearly this language, whether of gustatory or sensual appetite, goes far beyond the elaboration of the submerged metaphor of literary taste. It testifies to the reviewers' belief in the compelling impact of the novel on its readers, an impact the novel seldom has in our own era of far more explicit stimulations. Both the subject matter and also the reading process itself were believed to be sources of an intense pleasure that reviewers distrusted yet had to accept as the basis of the novel's success. In order to champion a better novel, reviewers had to persuade the public to accept a different kind of pleasure as the proper base for the reading experience. The novel offered a unique opportunity for "improvement" of the people; and reviewers, being didacts at heart, eagerly seized the chance. But it was a question how far the novel might be "improved" before it lost its popular appeal. Only if readers improved along with their novels could a new interaction be established on a higher, more intellectual level. And the issue was fundamentally confused by the lack of fit between various presuppositions about the audience, especially with respect to its age and gender composition.

In retrospect it appears likely that the desire of didacts, whether critics or authors, to raise the novel above its basis in pleasure had the eventual result of splitting the genre into the popular and elite forms we know today. (Of course one could argue that "elite" fiction, distinguished by earnest seriousness, is in reality middle-class.) The deliberately elite novel, and those earlier novels that can be reconstituted as elite productions, now hold sway in the academy. The public, if it reads novels at all, continues to read for story and for pleasure verging on painful excitement. In the 1840 os and 1850 s that result was still in the future, however, and the golden age of the novel was thought to be dawning. Reviewers saw that age as the age of the domination of fiction by the "better novel," whereas, as it now appears, it was rather the age in which a great variety of novels-intellectual and emotive, serious and ephemeral, moral and immoral-were all widely read by the ordinary reader. Like other golden moments, it was a moment of balanced tensions rather than consensus.

On the other hand it is true that reviewers in the mid-nine- 
teenth century, though speaking for a reading elite, were much more hospitable than their counterparts in our own day to a wide range of fiction and believed that the first test of any novel was its ability to create an unforced interest. And never-not in a single instance-did they talk about the act of reading novels as one of producing meanings, interpretations, or readings. The novel was a told story, not an expository genre; in whatever way they thought to improve the novel, the reviewers of this earlier day did not aspire to change its essential generic nature.

The closest they got to what academics take as the norm of reading fiction today-that is, interpreting it or constructing (or deconstructing) its meaning-was in discussions of the second reading, which novels occasionally merited. The second reading was a critical reading and different in kind from the first. It did permit a certain liberation from the bonds of the story. "We have not had time to read the book critically, but hurried through it for the story, by which we were led along and which does not flag at all" (Mirror, October 8, I 836). A critical reading was slower in pace than the first, but it was still based on pleasure and desire: "how many of the hundreds of novels, published every year, leave any impression on your mind or give you one afterthought about any character in them?" the American Review asked, considering Vanity Fair in October I848. "Say what you will, the book draws you back to it, over and over again." One goes back for a second reading because the book's interest is not exhausted by the first; the second reading provides new pleasures. Hands Not Hearts "will bear reading twice or thrice," the Literary World wrote on March 9, I 850, "first, for the story, which has a dramatic terseness, and afterwards for the study of character by means of a captivating style deprived of all mannerism." Julia Howard is "emphatically one to be read at a sitting, for the sake of the plot; and then to reread at leisure for the sake of the style" (Literary World, September I4, I 850); Kingsley's Hypatia is "entitled to two readings, one for its animated, stirring incident, another for the moral underneath the story" (Literary World, December I0, I853). This review went on to comment that "for our own parts, we hold the story to be much the more legitimate object of the two for a writer of fiction."

The proper object of the second reading, which was agreed to be a test of the worth of the novel, was the author's artistry, 
62 Novels, Readers, and Reviewers

appreciation of which, like the tonic or intoxicant or soothing effect of the first reading, was essentially pleasurable. "It possesses the great test of excellence, that it well sustains critical examination, revealing new beauties, upon familiar acquaintance, that were not obvious to a superficial inspection" (Harper's on Leather Stocking and Silk, August i 854). Hawthorne's tales "always deserve a double reading, one for the story and one for the art"; Amabel "merits reperusal as a study in the art of effective writing" (Home Journal, January 14, I 854; December 30, I854). All these pleasures rose from the foundation of the novel's primary appeal as a story, and it was altogether inconceivable that the second reading could replace the first. It was also impossible to imagine a novel without readers, for if the pleasures of the novel created a sort of dependency in its audience, the novel itself was formed to the shape of reader desire and thus contained the reader as an aspect of its form. 